Journal of Teacher Education for Sustainability, vol. 15, no. 1, pp. 107-120, 2013

\title{
WHY EDUCATION FOR SUSTAINABLE DEVELOPMENT NEEDS EARLY CHILDHOOD EDUCATION: THE CASE OF NORWAY
}

\author{
Kristin Gregers Eriksen \\ Telemark University College, Norway
}

\begin{abstract}
With this article, the author intends to outline a legitimising basis for implementing education for sustainable development (ESD) in early childhood education, in juridical, pedagogical and political terms. Starting from our current ecological crisis, the ontological assumptions of modern culture are considered obstructive to possibilities for mitigation. The author affirms a need for constructing new conceptual frameworks in the field of ESD suitable also for the youngest children. The very logic of the reigning notion of knowledge requires revision in order to secure successful implementation as well as fostering citizens with the moral agency required to meet calamity. Ontological insights from deep ecology are suggested integrated with the more practical epistemological concept of ecological habitus. Possible gains are not exclusively related to sustainability, but also include positive impacts on the life quality of young children as such.
\end{abstract}

Key words: early childhood education, kindergarten, cultural formation, habitus

\section{Introduction}

Following up on international initiatives on education for sustainable development (ESD) such as the United Nations [UN] Bonn Declaration (United Nations Educational, Scientific and Cultural Organisation [UNESCO], 2009), the Norwegian Directorate for Education and Training [UDIR] stated in a central strategic policy document that knowledge on sustainable development (SD) should imbue all levels of the educational system (UDIR, 2006). However, empirical studies implicate that this seldom pans out in practice (Raabs, 2010; Sinnes \& Jegstad, 2011). While SD as such has become an integral part of the language and justification of policy in Norway, educational practices tell of a different story. The absenteeism of sustainability issues might partly be related to the lack of competence and confidence in interdisciplinarity, a central pillar of and necessary methodological prerequisite for ESD, in current praxis. More significantly, the paradigmatic idea of modernity implicating that problems are to be split up and understood in purely atomistic ways seems to permeate educational thinking (Morin, 2001). The system is serving as apologist for the modern industrial society that brought about our current environmental struggles, as parts of the broad hegemonic process for "consumer dreamstructures" (O'Sullivan, 1999, p. 43). The focus of learning is weighted towards developing and accumulating technical knowledge, whilst emancipatory and agentive dimensions 
are principally deficient. The ecological crisis we are faced with today challenges this epistemology-based on substantial dualism, with its fundamental ontological division between nature and culture. Such logic has allowed natural resources to appear as inexhaustible sources that the Promethean human being can advantage from (White, 1967; Ingold, 1992). Approaches towards dealing with environmental and distributive challenges are in light of this characterised by a techno-rational logic (Bell, 1991). However, the complexities of environmental issues today reveal the inadequacy of the corresponding understanding of knowledge and epistemology.

Moreover, the understanding of ESD seems to be locked into a traditional logic of education in general and, more specifically, what has commonly been termed as environmental education, with hegemonic weight placed on the traditional 'hard' sciences. The importance of cultural and social aspects is not recognised, contradictory to the very purpose of SD with its interdependent dimensions. Importantly, this leads to a lack of integration of democracy and participation in educational practice and learning processes. However, seeing children as competent agents of change is integral to the implementation of ESD. Davis (2009) recognises this as the difference between education about, in and for the environment, arguing that the latter is commonly left out. In addition to the obvious pedagogical arguments in this context, this is not least highly problematic in light of children's relatively new won formal rights as citizens through the UN Declaration of the Rights of the Child (UNCRC) (UN, 1989). This also holds extensively true concerning the core values of the local juridical framework on education in Norway.

\section{Aims of the article}

As this article argues, if we are to achieve the goals of ESD, it is a necessary logical step to reconceptualise our very notions of environmental education, pedagogy and children's development as such. Fundamentally, this includes recognising the important role of early childhood education (ECE). As Sarronmaa and Sarronmaa (2009) point out, the educational system commonly meets ecological challenges either with suggesting isolated practical didactic solutions or emphasising the unclear relation between school policy and political will. The last strategy they suggest, that of establishing theoretical perspectives as foundations for pedagogic praxis, seems to be quite absent from the picture. Hereunder, the forthcoming work is intended as a contribution in this regard, but almost as much purely a legitimating basis for the necessity of turning efforts at the very ontological and epistemological foundations of current educational thinking and including also the very youngest of the system. Interestingly, the article shows that by integrating elements from ecological philosophy and practice theory with educational thinking, the conceptualisation of life quality for young children can also be addressed through the concept of ESD.

Thus, there are two inter-reliant aspects to be elucidated in the forthcoming, hereunder

1) the importance of understanding ESD as a process of social learning and a fundamentally value-based approach in order to develop new theoretical understandings;

2) the significance of an emerging new understanding of young children as citizens for transforming theoretical concepts into educational practice. 
The article is primarily intended to function as an outline of a situation and context, the scope is more broad than deep. However, a concept of ecological habitus is tentatively suggested as a starting point for further development of new theoretical frameworks.

\section{Presentation of the field}

\section{The Norwegian kindergarten tradition and ESD}

In the undoubtedly quite gloomy context of the conditions for ESD in Norway, a lacking focus on the youngest children is a particularly severe precedence. In the governmental strategy on ESD, ECE is briefly mentioned but not treated in further depth at all. On the one hand, this might be understood to reflect the above-mentioned focus on rationalistic knowledge, in that the pre-school sector in Norway traditionally has held an ambivalent attitude towards being included in the school system as such, given the strong and dominant social-pedagogic tradition in the field (Kunnskapsdepartementet [the Norwegian Ministry of Education and Research] [KD], 2009). This is especially connected with a resistance towards the concept of education. Discourse on kindergartens has been coloured by a parallel need of defining it as 'something different' in relation to school and, at the same time, legitimising it as school-preparatory in response to international as well as national political pressures (Oodegaard \& Krüger, 2012). Moreover, it might be related to views on the nature of the type of knowledge ESD involves as it is a common view to see the youngest children as too cognitively immature to be faced with the harsh realities of global environmental issues such as climate change (Edlev, 2008).

Not necessarily all wrong, this fails to recognise the dual advantages both in terms of children's cognitive development and well-being as well as reaching societal goals of SD with the implementation of ESD into ECE. UNESCO states that ESD "should be of a quality that provides the values, knowledge, skills, and competencies for sustainable living and participation in society" (UNESCO, 2009, p. 4). These values correspond strikingly well with the core goals in the Norwegian curriculum document for kindergartens (KD, 2011), where the holistic process of development and learning as Bildung (Norwegian danning) has precedence over pure knowledge acquisition. Additionally, the absence of ESD perspectives reflects the lack of an adequate conceptual framework for politically acknowledging, theoretically understanding as well as practically operationalising the connections between young children, participation and sustainability.

\section{A field with a plan}

In the curriculum and core strategic documents of the Norwegian kindergarten system, issues related to the environment and sustainability are commonly placed in a 'naturecategory'. Thus, the foundations are to be found in natural science subjects, whilst the crucial cultural dimension is disregarded. In the curriculum plan for kindergarten, aspects related to SD are placed under the headline "Nature, environment and technique", and only implicitly mentioned in terms of "environmental protection" (KD, 2009, p. 45). This reflects the permeating externalist idea of nature described above, as substantially different from us and something which needs to be protected due to its instrumental value to humans, neglecting its inherent value. More deeply, it is not sensitive to the pluralism of SD as such. While terms like skills and knowledge dominate school curri- 
culum, the idea of learning in kindergarten is concentrated towards competences and development in the broad sense. The approach is remarkably consistent with the core idea of ESD. "For the individual, SD is the capacity of lifelong learning and development, which is based on a person's all-round harmonious development" (KD, 2009, p. 13).

In fact, the term ESD might not even be sufficient to understand the whole picture; we should perhaps aim for educating for a sustainable citizenship as such, related to the choices of everyday life and sustainability as concrete, lived experience (Gadotti, 2008). This is however in no way discipline-specific and should not be confined to natural sciences alone. As Otto and Wohlpart (2009) write, the humanities are especially well disposed to effect values and beliefs and thus effect change in cultural and cognitive systems. After all, the technological and economic solutions proposed will have to be undertaken and interacted with by living human beings. What is more, in the European strategy for ESD developed by the United Nations Commission for Europe [UNECE], it is made clear that both formal and informal learning contexts are fundamental (2003). Thus, there is no factual opposition between a highly social-pedagogical kindergarten ideal and integration of ESD in plans, ideas and practices of learning for the youngest children; rather the opposite. Educating for a more sustainable future is at the core not solely about meeting and mitigating 'challenges', but more deeply interconnected with the quality of life by emphasising problem solving, critical thinking skills and "democratic means of promoting values" (Huckle, 1999, p. 38). The interconnectedness between life quality, education and developing self-identity is thus incorporated in the very term. This will in the forthcoming be illustrated by adding insights from deep ecology and place pedagogies to serve as proposed motivational structures.

\section{Central terms}

\section{Young children - what are they?}

In the context of the Norwegian kindergarten, the children discussed are at the ages 1-5 years old. After institutions for young children were organised by national law in 1975 , the number of children receiving such services has skyrocketed. Today, around $90 \%$ of children attend kindergarten, and many spend as much as 40 hours per weeks there. The new reality of everyday life for the youngest members of society has spurred media debates and made governmental attention within the field more substantial. Contrary to what is described in Davis (2009) on the complexity and diversity of the ECE systems in many countries, the kindergarten sector in Norway is made quite uniform through substantial central governance. Its social-pedagogical tradition has always kept 'care' at its centre, but is increasingly challenged by material realities of the institution as well as the much powerful political discourse of learning. Although the responsibility for providing children with joy, care and well-being is firmly asserted in the national laws for kindergarten, the visions of objective rationality is lurking in the background. Already in 1996, the project "Making Lifelong Learning a Reality for All” was launched by the Organisation for Economic Cooperation and Development [OECD], and education in a life-span perspective became part of public debate in Europe (Juell, 2010). With the reports "Starting Strong” (OECD, 2001, 2006) the kindergarten sector in Norway was truly integrated in the educational sector through the concept of lifelong learning. This is, however, a concept of learning strongly grounded in the neoliberal discourse, which 
comes with economic connotations, making the learning process figure in a logic of a transaction where the pupil receives 'goods' (Biesta, 2009). Quality is hence commonly understood as quantifiable results and the achievement of standardised goals. Among the highly debated issues of kindergartens is the increase in pressure to apply mapping tools and formal testing of children's basic skills in language and mathematics (Oostrem, 2009).

So what is then 'education' and 'learning' when it comes to the youngest children? In this context, there is a need to distinguish between different ideological views of what children fundamentally are in social terms. Seeing children and childhood as historically flexible and thus socially constructed is by no means controversial, and Aries (1973) argued that the idea of childhood as such is a modern invention. The ideas of children in modern sociology can be roughly divided into two ideological categories. One perspective regards children as becomings who are naturally set to develop gradually into adult human beings and hence should be considered 'unfinished'. The other strand understands children as beings in themselves and thus as competent citizens (James, Jenks, \& Prout, 1998). The roots of modern pedagogy and educational thinking have been cut out by the former, cultivating our positivistic need to control, form and standardise to preserve order (Steinsholt \& Oksnes, 2003). In this view, we 'produce' adults through education that is cut out to fit the modern society that actually brings about our current environmental troubles.

\section{Learning and cultural formation}

Current research traditions are more commonly based on social constructionist views where children are understood as social actors with agency, quite different from older universalistic traditions such as development psychology and functionalistic sociology (Lysaa, 2012). Children are seen as competent individuals forming their own lives and identities. Here the Norwegian concept of danning can be key to developing a more adequate theoretical platform for implementing ESD as education for the environment. The term can be traced back to the ancient Greek paideia, the Socratic dialogue, critical thinking and active learning as core. It was later revived but the bourgeoisie enlightenment as bildung, bringing with it connotation problems, appearing highly normative and associated with class-specific ideals of the bourgeoisie enlightenment (Ariansen, 2011). However, by applying the term cultural formation as an alternative understanding, the processual aspects as well as participation are emphasised (Oodegaard \& Krüger, 2012). In the Norwegian context, cultural formation has been defined as a lifelong process of versatile self-development (KD, 2009). Applying this concept thus frees us from the passive picture of the child as mere receiver and opens for an integration of sustainability as a tool for better life quality and self-development. Moreover, it allows for seeing ESD as something that both can and must be approached already with the youngest children, as cultural formation is a process that principally can be understood to start already at birth and in principle never ends (Oodegaard \& Krüger, 2012). Furthermore, as Samuelsson (2011) argues, foundations for knowledge construction as well as attitudes and values are formed in the early years. She illustrates this by referring to a set of interviews undertaken with pre-school children in Australia, demonstrating that their thinking of the state of the world actually connects with the holist concept of SD. They see links between waste, the well-being of the earth and quality of life for human beings. 
Moreover, this must be seen in relation to their own interests, understandings and cultural contexts. Children's participation will, of course, always entail recognition of their individual points of view.

\section{The child as citizen}

Within the discourse on the competent child, the development of children's formal rights is a central pillar. This is strongly related to the UNCRC and most notably in terms of $\$ 12$ on children's right to participation. Although the convention has been ratified by all UN nations except the United States of America and Somalia, $\mathbb{1 2}$ is highly controversial, and many countries have used their right to modification on this (Smith, 2008). In the context of Norway, children's right to participation has been thoroughly incorporated in national law in general, and it has become a central principle in juridical documents regarding kindergartens. The strengthening of children's individual rights has been referred to as a development where children are recognised as citizens (Kjorholt, 2010). However, formal rights are not the same as factual rights, and precisely how this principle is to be translated into practical terms is vague and thus heavily debated. Acknowledging children as citizens also serves as a platform for arguing for the importance of ESD for young children. Although the pedagogical and social imperatives might be clear, ESD still seems difficult to prioritise in curriculum and strategy plans. This is contradictive to the inherent ethical implications in the definition of sustainability as such. SD was initially defined as development that meets the needs of the present without compromising the ability of future generations to meet their own needs (World Commission on Environment and Development [WCED], 1987). Thus, it makes strong implications on the responsibility of current generations towards the future. Philosophers have commonly coined the moral responsibility in terms of an imperative resting on Western countries towards the poorer parts of the world, arguing that we have a negative moral duty to not make matters worse for the people that are and in the future will be negatively affected by climate change (Pogge, 2002). This logic bears hold also for children, not only as representatives for 'future generations' of this intergenerational justice, but also in terms of the fundamental principles in UNCRC. These include not only their right to participation but not least the principles of prioritising the best interests of the child $(\$ 3)$ and the right to life and development $(\$ 6)$. There is thus a legal imperative towards facilitating a sound use of natural resources for new generations, something which fits straight into the fashionable discussions on children's participation in ECE institutions as well as the case of ESD in ECE.

\section{Discussion}

\section{Developing identity and learning for sustainability}

Young children do hereunder not merely represent a target-group among others, but even more so important resources in reaching the goal of integrating a holistic cultural understanding of SD. Simultaneously, ESD approaches and ways of thinking also have potentially important contributions for children's cultural formation and quality of life in itself. The currently flashing warning lights of increasing weight and physical health problems among Western children as well as psychological and cognitive disorders have 
by Louv (2005) been related to the disconnection of children from their natural environment as a kind of 'nature-deficit-disorder'. Psychiatrists have pointed to a possible connection between children's detachment from nature and overprotection, with mental health challenges such as depression and anxiety. Such alarming developments are contextualised within core aspects of modern culture. Regardless of the potential relations here, possible gains of interacting with nature are well documented. Furthermore the thesis that aspects of modern culture and societal structures have problematic impacts on identity formation has been coined in many ways, joint by the notion that it makes for insecure children with its high demands of reflexivity (Hoèm, 1978; Ziehe, 1989; Glaser, 2011).

The need for experiencing correspondence between felt expectations and actual experiences is what Giddens described as ontological security (1991), denoting a kind of stable mental state and self-identity. Meaning is hence found in experiencing positive emotions and by avoiding chaos and anxiety. This is reliant on the individual's ability to give meaning to her life, which is fundamental for self-confidence and well-being. Children create meaning and understand their surroundings through processes of autopoiesis (Luhmann, 1995), in dialectic interplay with their surroundings. This process is especially closely connected to the body, as one thinks and experiences through and with the body. Yet, for children this pre-reflexive epistemology is completely dominating their experiences (Merleau-Ponty, 1984). Furthermore, in contrast with adults, young children have a generally gestalt-orientated epistemological sense that is lost somewhere along their socialisation process toned towards the specialisation of modern society (Jakobsen, 2005). Seeing nature and culture as detached spheres are hereunder stages in an 'unnatural' process of learning to see oneself as external to nature. Empirical studies support this notion that understanding inherent connections in nature is an ability that is developed at an early age (Phenice \& Griffore, 2003). This is integrated with children's moral self development. Children show concern for their natural surroundings already before they experience acknowledgement of their self-identity, and the experience of acting morally is part of creating an understanding of oneself as a moral agent with capabilities. Numerous studies implicates that a positive environmental ethical attitude is deeply interconnected with early play in and interplay with nature (Chawla, 1988). Hence, internalising sustainability as intrinsic part of moral agency is something that should and, perhaps also must, start during the years of kindergarten and pre-school.

\section{Feeling at peace in a protected place}

The fractured and unstable characteristics of modern identity formation have led to acknowledgement of our disembeddedness from place (Giddens, 1991) as a representative for ontological security. The externalist ideas of knowledge and nature have not least been severely challenged by the physical realities of the environment literally 'moving closer'.

In fact modern man for a long time believed that science and technology had freed him from a direct dependence on places. This belief has proved an illusion; pollution and environmental chaos have suddenly appeared as a frightening nemesis, and as a result the problem of place has regained its true importance (Schulz, 1984, p. 19). 
This is related to the cognitive challenge of grasping the realities of environmental issues in their essentially global character and its associated problems of placing cause and effects on a comprehensible scale. Reality is that for most people it is far to Greenland and a long time until 2050. Place-oriented pedagogies are thus needed so that the education of citizens might have some direct bearing on the well-being of the social and ecological places people actually inhabit (Gruenewald, 2003). Place is, in the phenomenological sense, understood as particular lived place-worlds of human beings (Birkeland, 2011). It involves both the subjective and objective forms of the world around the individual human being, and, in relation to children's development, this is in phenomenological terms described as the lifeworld. Place thus becomes a qualitative, total phenomenon that cannot be reduced to its individual, material pieces. It can be described as dwelling or "being at peace in a protected place" (Schulz, 1984, p. 22). In this view, place is related to modern identity formation, stimulating ontological security. Local surroundings and places can become links between children's harmonious cultural formation and SD. The importance of taking the local as point of departure in strategies for SD is embedded in the concept from its first official documents and definitions. Ideas of local action and global impacts are bearing principles in the UN global action plan "Agenda 21" (United Nations Committee on Education and Development [UNCED], 1992). The local place, or the bioregion, can stimulate attention and identification with the web of life at all levels (O'Sullivan, 1999). Samuelsson (2011) makes clear how the understandings children have of sustainability at a young age are interconnected with their immediate contexts. The children interviewed about the state of the world in Australia, thus related it to bush fires and koala bears.

The importance of place in the existential way is where fundamental insights can be added from deep ecology. The ontological theory of Arne Naess and the basis for deep ecology is based on the holist idea that "everything is connected to everything" (Naess, 1999, p. 15), in opposition to the atomistic picture permeating the modern mechanistic world view. The insight that human beings cannot separate their selves from the greater whole of the world is not to be understood as neither relative nor subjective, but rather as a way of theorising the intrinsic relationality of all things (Diehm, 2006). One could here object that deep ecology is explicitly non-anthropocentric and thus seemingly not compatible with pedagogy, which unalterably has human beings as end. This is also at the root of the barriers for obtaining the goals that SD promise, all the while anthropocentrism is interwoven with the very term. As McShane (2007) writes, anthropocentrism is the view that the non-human world has value only because, and, insofar as, it serves human interests. Although it may well appear that deep ecology 'wipes away' the self and dismisses it as relations, Naess is on the contrary well sensitive to the cultural and biological distinctiveness of human beings in more than anything our ability of self-consciousness. This also gives us a special responsibility towards other living beings that lack this capacity (Naess, 1999). Moreover, self-realisation is constantly the ultimate goal for Naess, not as maximisation of one's narrowly construed interests or with 'colossal ego-trips', but in the deep recognition of the true depth of the connection with nature (Diehm, 2006). The core of deep ecology is not a dogmatic programme, but a committed attitude (Naess, 1999). A motivational structure in this sense seems logically imperative. Educational practice must dare to acknowledge its moral aspects, the inherent value rationality where certain modes of action are assigned inherent value. 


\section{Towards a concept of ecological habitus}

If stopping at individual identity formation, there is little room for the talk of social change which ESD brings with it. This is also true when considering the link between individual development and societal aspects inherent in cultural formation. How may then the ontological insights gained from the gestalt thinking of deep ecology be integrated with a theory of practical action that also can bear meaning for pedagogies? Although vastly criticised and accused for being a sort of theoretical deus ex machina (Lizardo, 2004), Pierre Bourdieu's concept of habitus have a lot to offer in this regard. The notion of autopoeisis makes it logically impossible to form children in instrumental ways; because we cannot predict the outcome of the self-creating processes of each individual. The modern mechanistic paradigm is here not just 'untrue' in the Naessian logic, it has also been argued to alienate and estrange human beings from their true nature. The instrumental and individualist logic eradicates authenticity and pulls human beings away from their true selves. This can thus be seen in connection with children's possible inharmonious self-development (Nyeng, 2000).

Bourdieu illustrates the social aspects of relationality. With him, the body is situated in social fields, and individual acts of perception (noesis) are made against a background of existing categories of thought (noemata) incorporated in the body. The body is in the world but, importantly, the social world is also in the body (Bourdieu, 1984). Habitus is commonly misunderstood to represent an objective, reductionist element, leading Bourdieu into the trap of structuralism and determinism that he so explicitly sought to avoid. However, this is to disregard the way the concept allows for going beyond a phenomenological focus of the lived experience of the social world and point to the correspondence between objective and internalised structures (Bourdieu, 1990). One might actually describe this approach as a 'cognitive sociology' (Lizardo, 2004), as there is an association between social structures and mental structures. Such a cognitive sociology hence pays attention to the historical development of schemata of perception. Here children's individual development and the movement of society at large towards SD can meet. Cognitive and social structural developments are dialectic and continuously ongoing processes, where the objective social structures are translated through individual processes of self-development. The basic idea is that when SD becomes integral in the cultural formation of children, it will eventually influence the structures of our society through their choices of better practices, and the structures will again foster sustainable practices and so forth. It will eventually become a 'good circle'.

Habitus is made up by capital, and Bourdieu emphasises how capital is related to the potential in having a lasting network and relations marked by mutual recognition (1986). This can be related to human interaction with nature, which seems to be morally guided by exactly a sense of reciprocity and duration (Chawla, 1988). By suggesting the idea of ecological habitus and ecological capital, we allow for theorising this further. Capital is internalised in the semi-reflexive habitus as generative structure or dispositions for practical action (Bourdieu, 1990). Understood this way, habitus comprises both restrictions to and ability for practical agency. This sheds light to the idea that children who interact with nature from an early age, are more prone to develop positive environmental attitudes as adults (Broch, 2004). The dispositions of habitus are persistent, but not absolute, and the main formative period is early childhood. Moreover, they are bodily embedded. This is why it is fundamental to integrate SD into children's develop- 
ment of ecological habitus already in the earliest years. Moreover, the concept transcends a focus on accumulation of abstract knowledge, as it emphasises practical action and competencies and possibilities for action. Hence there is a focus on mastery and the possibilities which include social relations as well as the physical environment. An appropriate allegory here is the common idea in social anthropology of coping and the human bricoleur, who lives in accord with and simultaneously manages to advantage from her environment (Croll \& Parkin, 1992). This is an argument for making the complex issues of SD core in ECE, to foster the creativity and interest of young children and stimulate their cultural formation. As some may argue that we make children scared or feel guilty about the ecological crisis and global injustice, the exact opposite is actually done when they are given the understanding and experience that they can influence and think about new ways themselves (Samuelsson, 2011).

Although at some points operating in different scientific realms, both Bourdieu (1990) and Naess (1999) can be seen to have in common an opposition to views that distinguish between reality as experienced and reality independent of our existence. This might be the most important theoretical premise and insight for obtaining pedagogies adequate for implementing ESD in ECE. The modern mechanistic paradigm is based on the Galilean divide between the primary and secondary qualities of things and nature, where nature is allowed to be, firstly, something in itself and apart from us and, secondly, something human beings experience as subjects towards objects (Diehm, 2006). Here lies much of the root of the logic which invariably lets us see the value of nature as instrumental and thus can leave ESD with the mere 'protection of nature' logic. Outdoor kindergartens can serve as examples on how good efforts are stuck in a romantic view of nature as something out there, wild nature as a radically different context from the ordinary everyday life. The idea is that being outside is 'good for children'. This is an example of environmental education as education in the environment, again leaving out education for. This notion of nature as 'the thing in itself' is in both the Naessian and the Bourdieuian logic an abstraction. While deep ecology serves important ontological premises for ESD, establishing the idea of ecological habitus can serve as a move towards more practical, pedagogic tools. It constitutes the difference between education aiming at behaviour modification and education aiming at action competence and, in the societal sense, a shift of focus from human beings as consumers of goods and information to active and capable citizens. The ideology of making resource use serve the quality of life rather than the economic standard of living as generally promoted by consumerism has its clear parallel in the case of children. We must make pedagogy serve the quality of life of children and not only be steered by market mechanisms of the modern, economist logic.

\section{Concluding reflections}

Through this article, a legitimatising basis for why ESD should not overlook ECE has been outlined in the context of Norway. It has become clear that there are moral imperatives for including the youngest children in the work towards SD, and pedagogical implications for how the process of cultural learning can gain from perspectives of sustainability have been pointed out. A social learning perspective is suggested integrated through applying the concept of ecological habitus. However, the theoretical construction must be further investigated with insights from further empirical enquiry. 
Further responses to the challenges of implementing ESD into ECE should include research capacity building, in order to improve capacity on the subject, creating international networks and stimulating and initiating further initiatives and funding (Davis, 2009). Moreover, a particularly important aspect is to take research into professional learning and hence look further into the conditions of ESD in teacher education related to ECE. This is quite interesting in the context of Norway, as a new framework plan for kindergarten teacher education is currently being implemented. The major novelty of the plan is a reorganisation of traditional scientific disciplines into practically oriented, interdisciplinary fields of knowledge. This corresponds well with core ideas of ESD, at least theoretically, and might represent a fruitful context for developing a better understanding of what ESD can represent for ECE.

Nevertheless, there seems to be a common ground fusing the emerging new understanding of children as democratic citizens and agents and the urgent need for taking $\mathrm{SD}$ into practice. The challenge is to gain recognition for ECE as an imperative starting point.

\section{References:}

Ariansen, P. (2011). Hva er dannelse? [What is bildung?]. In B. Hagtvet \& G. Ognjenovic (Eds.), Dannelse. Tenkning - Modning - Refleksjon [Bildung. Thinking - maturing reflection] (pp. 39-55). Oslo: Dreyer.

Aries, P. (1973). Centuries of childhood. London: Pimlico.

Bell, D. (1991). The winding passage. Sociological essays and journeys. London: Transaction Publishers.

Biesta, G. (2009). Laering retur [Beyond learning]. Copenhagen: Unge paedagoger.

Birkeland, I. (2011). Cultural sustainability: Industrialism, placelessness and the reanimation of place. Ethics, Place \& Environment, 11(3), 283-297.

Bourdieu, P. (1984). Distinction. Cambridge, MA: Harvard University Press.

Bourdieu, P. (1986). The forms of capital. In E. G. Richardson (Ed.), Handbook for theory and research for the sociology of education (pp. 241-258). New York: Greenwood.

Bourdieu, P. (1990). The logic of practice. Stanford, CA: Stanford University Press. Bourdieu, P. (1998). Practical reason. On the theory of action. London: Polity Press.

Broch, H. B. (2004). Barndommens gronne dal - om betydningen av barns naturopplevelser [The green valley of childhood - on the significance of experiences of nature in childhood]. Norsk Antropologisk Tidsskrift [Norwegian Journal of Anthropology], 15(1-2), 101-113.

Chawla, L. (1988). Children's concern for the natural environment. Children's Environments Quarterly, (5)3, 13-20.

Croll, E., \& Parkin, D. (1992). Anthropology, the environment and development. In E. Croll \& D. Parkin (Eds.), Bush base, forest farm: Culture, environment and development (pp. 3-10). London: Routledge.

Davis, J. M. (2009). Revealing the research "hole" of early childhood education for sustainability: A preliminary survey of the literature. Environmental Education Research, 15(2), 227-241.

Diehm, C. (2006). Arne Naess and the task of gestalt ontology. Environmental Ethics, $28(1), 21-35$. 
Edlev, L. T. (2008). Natur og miljo i paedagogiske arbeide [Nature and the environment in pedagogy]. Kobenhavn: Special-Trykkeriet Viborg.

Gadotti, M. (2008). What we need to learn to save the planet. Journal of Education for Sustainable Development, 2(1), 21-30. DOI: 10.1177/097340820800200108.

Giddens, A. (1991). Modernity and self-identity. Cambridge: Polity Press.

Glaser, V. (2011) Individualisering av barnet - nye tider og nye krav til det moderne foreldreskap [Individualisation of the child - new times and new demands for modern parents]. In V. Glaser \& J. Bolstad (Eds.), Moderne oppvekst. Nye tider nye krav [Growing up today. New times - new demands] (pp. 5-18). Oslo: Universitetsforlaget.

Gruenewald, D. A. (2003). The best of both worlds: A critical pedagogy of place. Educational Researcher, 32(4), 3-12. DOI: 10.3102/0013189X032004003.

Hoèm, A. (1978). Sosialisering: en teoretisk og empirisk modellutvikling [Socialisation: Theoretical and empirical modelling]. Oslo: Universitetsforlaget.

Huckle, J. (1999). Locating environmental education between modern capitalism and postmodern socialism: A reply to Lucie Sauve. Canadian Journal of Environmental Education, 4(1), 36-45.

Ingold, T. (1992). Culture and the perception of the environment. In E. Croll \& D. Parkin (Eds.), Bush base, forest farm. Culture, environment and development (pp. 3956). London: Routledge.

James, A., Jenks, C., \& Prout, A. (1998). Theorizing childhood. London: Polity Press. Jakobsen, T. G. (2005). Okofilosofi-Okologi, evolusjonsteori og transformativ laering [Ecophilosophy - ecology, theory of evolution and transformative learning]. Trondheim: Tapir akademisk forlag.

Juell, E. (2010). Barnehagen som utdanning [Kindergarden as education]. Oslo: Cappelen Damm.

KD (Kunnskapsdepartementet [The Norwegian Ministry of Education and Research]). (2009). White paper 41 (2008-2009). Kvalitet i barnehagen. Oslo: The Norwegian Ministry of Education and Research.

KD (Kunnskapsdepartementet [The Norwegian Ministry of Education and Research]). (2011). Framework plan for the content and tasks of kindergartens (R-11). Bergen: Fagbokforlaget.

Kjorholt, A. T. (2010). Barn som samfunnsborgere [Children as citizens]. Oslo: Universitetsforlaget.

Lizardo, O. (2004). The cognitive origins of Bourdieu's habitus. Journal for the Theory of Social Behaviour, 34(4), 375-401. DOI: 10.1111/j.1468-5914.2004.00255.x.

Louv, R. (2005). Last child in the woods. Saving our children from nature-deficit disorder. Chapel Hill, NC: Algonquin Books of Chapel Hill.

Luhmann, N. (1995). Social systems. Stanford, CA: Stanford University Press.

Lysaa, I. M. (2012). Danningsbegrepet som analytisk begrep i lys av nyere barndomssosiologi [The concept of cultural formation in light of modern sociology of childhood]. In E. E. Oodegaard (Ed.), Barnehagen som danningsarena [The kindergarten as arena for cultural formation] (pp. 49-68). Bergen: Fagbokforlaget.

McShane, K. (2007). Anthropocentrism vs. nonanthropocentrism: Why should we care? Environmental Values, 16(2), 169-185. DOI: 10.3197/096327107780474555.

Merleau-Ponty, M. (1984). The structure of behaviour. Pittsburgh: Duquesne University Press. 
Morin, E. (2001). Seven complex lessons in education for the future. Paris: UNESCO. Nyeng, F. (2000). Det autentiske menneske [The authentic human]. Bergen: Fagbokforlaget.

Naess, A. (1999). Okologi, samfunn og livsstil [Ecology, society and lifestyle]. Oslo: Bokklubben.

OECD (Organisation for Economic Cooperation and Development). (2001). Starting strong. Early childhood education and care. Paris: OECD.

OECD (Organisation for Economic Cooperation and Development). (2006). Starting strong II. Early childhood education and care. Paris: OECD.

Oodegaard, E. E., \& Krüger, T. (2012). Studier av barnehagen som danningsarena sosialepistemologiske perspektiver [Studying kindergarten as arena for cultural formation - social-epistemological perspectives]. In E. E. Oodegaard (Ed.), Barnehagen som danningsarena [The kindergarten as arena for cultural formation] (pp. 19-42). Bergen: Fagbokforlaget.

Oostrem, S. (2009). Alle teller mer [Everyone counts more]. Report number 1/2009. Tonsberg, Norway: Vestfold University College.

O'Sullivan, E. (1999). Transformative learning: Educational vision for the 21st century. Toronto: University of Toronto Press Inc.

Otto, E., \& Wohlpart, J. (2009). Creating a culture of sustainability: Infusing sustainability into the humanities. Journal of Education for Sustainable Development, $3(2), 231-235$.

Phenice, L., \& Griffore, R. (2003). Young children and the natural world. Contemporary Issues in Early Childhood, 4(2), 167-178.

Pogge, T. (2002). World poverty and human rights. Cambridge: Polity Press.

Raabs, N. (2010). No child in the Norwegian woods? A study on education for sustainable development in Norwegian primary schooling. Retrieved June 17, 2013, from https://www.duo.uio.no/bitstream/handle/10852/32611/Thesis_NKR_DUO. pdf? sequence $=1$

Samuelsson, I. P. (2011). Why we should begin early with ESD: The role of early childhood education. International Journal of Early Childhood, 43(2), 103-118.

Sarronmaa, R., \& Sarronmaa, S. (2009). Et teoretisk bidrag til en miljorettet pedagogikk [A theoretical contribution towards an environmental pedagogy]. Norsk Pedagogisk Tidsskrift [Norwegian Journal of Pedagogy], 1(9), 67-75. Retrieved June 17, 2013, from http://www.idunn.no/ts/npt/2009/01/et_teoretisk_bidrag_til_en_miljorettet_ pedagogikk

Schulz, C. N. (1984). Genius loci. Towards a phenomenology of architecture. New York: Rizzoli.

Smith, L. (2008). FNs konvensjon om barnets rettigheter [The UN convention on the rights of the child]. In N. Hostmaelingen, E. S. Kjorholt \& K. Sandberg (Eds.), Barnekonvensionen [The convention on the rights of the child] (pp. 17-29). Oslo: Universitetsforlaget.

Sinnes, A. T., \& Jegstad, K. M. (2011). Utdanning for baerekraftig utvikling: to unge realfaglaereres mote med skolehverdagen [Education for sustainable development: Two young science teachers and their meeting with everyday life in schools]. Norsk Pedagogisk Tidsskrift [Norwegian Journal of Pedagogy], 91(4), 248-258. Retrieved June 17, 2013, from http://www.idunn.no/ts/npt/2011/04/art07?highlight=\# highlight 
Steinsholt, K., \& Oksnes, M. (2003). “Stop making sense!” Perspektiver paa barn og barndom [Perspectives on children and childhood]. In S. Sagberg \& K. Steinsholt (Eds.), Barnet. Konstruksjoner av barn og barndom [The child: Constructions of children and childhood] (pp. 19-44). Oslo: Universitetsforlaget.

UDIR (Utdanningsdirektoratet [The Norwegian Directorate for Education and Training]). (2006). Nasjonalt dokument for utdanning for baerekraftig utvikling $i$ grunnopplaeringen [National document for education for sustainable development in primary schools]. Retrieved February 24, 2012, from http://miljolare.no/innsendt/ pdf/oppslag/39/45be039ab1383/fns_utdanningstiar_for_barekraftig_utvikling.pdf

UN (United Nations). (1989). The convention on the rights of the child. Retrieved February 24, 2012, from http://www2.ohchr.org/english/law/crc.htm

UNCED (United Nations Committee on Education and Development). (1992). United Nations committee on education and development. Agenda 21. Retrieved February 20, 2013, from http://www.unep.org/Documents.Multilingual/Default.asp? documentid $=52$

UNECE (United Nations Economic Commission for Europe). (2003). Regional strategy on education for sustainable development. Retrieved February 2, 2012, from http://www.unece.org/environmental-policy/areas-of-work/education-forsustainable-development-esd/about-us/the-strategy.html

UNESCO (United Nations Educational, Scientific and Cultural Organisation). (2009). The Bonn declaration. Retrieved February 24, 2012, from http://www.esd-worldconference-2009.org/fileadmin/download/ESD2009_BonnDeclaration080409.pdf

WCED (World Commission on Environment and Development). (1987). Our common future. Oxford: Oxford University Press.

White, L. T. J. (1967). The historical roots of our ecologic crisis. Science, 155(3767), 1203-1207.

Ziehe, T. (1989). Kulturanalyser [Cultural analysis]. Stockholm: Symposion.

\section{Correspondence:}

Kristin Gregers Eriksen, Assistant Professor in Social Sciences, Telemark University College, Faculty of Art, Folk Culture and Teacher Education, Postboks 842, 3007 Drammen, Norway. Email: Kristin.g.eriksen@hit.no 